DOI: $10.22363 / 2312-9182-2018-22-4-770-787$

\title{
The Catalogue of Semantic Shifts: 20 Years Later
}

\author{
Anna A. Zalizniak \\ Institute of Linguistics of the Russian Academy of Sciences \\ 1 B. Kislovskij Ln., Moscow, 125009, Russia
}

\begin{abstract}
The article summarizes the goals and the current state of the Catalogue of sematic shifts (CSSh), its primary notions being those of a semantic shift, which is understood as a relation of cognitive proximity between two linguistic meanings, and a realization of a semantic shift, i.e. one polysemic word or a pair of cognate words of the same language or different languages that act as "exponents" of this relation. The typology of semantic shifts occupies a position at the crossroad of semantic, lexical and grammatical typologies, overlapping each of these areas of study in terms of linguistic data and methods used; however, the domain of CSSh does not coincide with any of them. The framework of CSSh provides the theoretical foundation for identifying recurring cross-linguistic semantic shifts, and collecting them in the Database of Semantic Shifts for further analysis. The article demonstrates that the notion of semantic shift as defined in CSSh is just a formalization of an instrument of linguistic analysis that is already quite common in various areas of linguistics. Semantic shift provides a basis for the notion of semantic parallel used in the historical linguistics and etymology, for motivational models in word-formation, it is a central notion for grammaticalization theory; finally, semantic shift is one of various types of implicit meanings (along with presuppositions and connotations) that shape the "linguistic model of the world". Linguistic data contained in the Database of Semantic Shifts can be used in all these areas, in order to provide semantic plausibility criteria for linguistic reconstruction, to act as empirical evidence for cognitive mechanisms of linguistic conceptualization, to aid in identifying specific features of the semantic system of a given language or group of languages.
\end{abstract}

Keywords: semantic shift, semantic derivation, polysemy, semantic typology, lexical typology, semantic evolution, semantic parallel

\section{Каталог семантических переходов: 20 лет спустя}

\author{
Анна А. Зализняк \\ Институт языкознания Российской академии наук \\ Россия 125009 Москва, Б. Кисловский пер., д. 1
}

В статье излагается актуальное состояние концепции Каталога семантических переходов (КСП), основными категориями которой являются семантический переход, понимаемый как отношение когнитивной смежности между двумя языковыми значениями, и понятие реализации семантического перехода, т.е. слово или пара слов того или иного языка (языков), являющиеся «экспонентом» этого отношения. Область типологии семантических переходов находится на пересечении областей семантической, лексической и грамматической типологий, не совпадая ни с одной из них. Концепция 
КСП является инструментом выявления и описания семантических переходов, воспроизводимых в языках мира в форме синхронной полисемии, диахронической семантической эволюции и в ряде других. При этом принимаемое в КСП понятие семантического перехода представляет собой формализацию представления, которое de facto давно и широко используется в разных областях лингвистики: на него опирается понятие семантической параллели, применяемое в этимологии, понятие мотивационной модели в словообразовании; семантический переход является центральной категорией теории грамматикализации и когнитивной диахронической семантики; семантический переход представляет собой один из типов имплицитных семантических отношений, формирующих «языковую картину мира». Языковой материал, содержащийся в Базе данных семантических переходов, может быть использован для формирования семантического критерия реконструкции, для выявления когнитивных механизмов языковой концептуализации, для описания типологических и ареальных особенностей семантических систем.

Ключевые слова: семантический переход, семантическая деривация, полисемия, семантическая типология, лексическая типология, семантическая эволючия, семантическая параллель

\section{INTRODUCTION}

In the twenty years that have passed since the idea behind The Catalogue of Semantic Shifts (CSSh) first emerged, numerous research projects with similar objectives and methodology have been launched. Consequently, lexical typology has developed from a marginal domain of linguistic typology into a leading trend not only within typology but in linguistics generally, providing a sphere in which to apply some of its newest ideas and methods.

The framework of CSSh has been in development since 1998, beginning within the scope of my project on the typology of semantic derivation supported by the RFBR (Russian Foundation for Basic Research). Since 2002, the implementation of the CSSh in the form of the Database of Semantic Shifts in the Languages of the World (DatSemShift) has been carried out by a working group at the Institute of Linguistics of the Russian Academy of Sciences (Maria Bulakh, Dmitry Ganenkov, Ilya Gruntov, Timur Maisak, Maxim Russo, and Anna A. Zalizniak). From 2005 to 2009, our project was part of the international project "Core Vocabulary in a Typological Perspective: Semantic Shifts and Form/Meaning Correlations" supported by INTAS (The International Association for the Promotion of Cooperation with Scientists from the New Independent States of the Former Soviet Union) with Maria Koptjevskaja-Tamm as project coordinator. Information about the conceptual idea of CSSh, the architecture of the database (DatSemShift) in which it is implemented, and some preliminary conclusions concerning the occurrence of semantic shifts in the languages of the world may be found in Zalizniak 2001, 2008, 2009, 2013a, Gruntov 2007, Zalizniak et al. 2012. From 2013 until the spring of 2018, the DatSemShift has been available online at http://semshifts.iling-ran.ru/. Elaboration of the CSSh framework and further development of the database are being conducted currently at the Institute of Linguistics within the scope of the project "Cognitive Mechanisms of Semantic Derivation in Light of typological data" by a working group (Maria Bibaeva, Tatjana Mikhajlova, Maria Orlova, Maksim Russo, Anna Smirnitskaya and Mikhail Voronov) under my guidance. A revised version of the Database of Semantic Shifts (DatSemShift.2.0) will be available at http://datsemshift.ru/ by the end of 2018 . 
In this article, I would like to summarize the goals and the current conceptual state of CSSh and to determine its relationship to the contiguous areas of modern typological studies.

\section{SEMANTIC SHIFT AS EXTENDED POLYSEMY}

In CSSh, semantic shift (SSh) is understood as a cognitive proximity ${ }^{1}$ of two meanings A and B (or SOURCE-meaning and TARGET-meaning) that manifests itself in the fact that these two meanings are conflated within the limits of one word in an extended sense (see below the list of realization types) ${ }^{2}$. No special metalanguage for the representation of meanings is presupposed - instead, we denote meanings A and B using elaborately developed semantic labels. English words which are unambiguous or have an obviously "main" meaning serve as such labels; if no appropriate word can be found, short formulas (e.g. 'to have opinion') or specifications in brackets like 'to turn, rotate (tr.)', 'right (vs. left)', 'to deliver (a child)' may serve this purpose.

During the discussion of my presentation of the CSSh at the Australian National University (Canberra) in November 2003, Anna Wierzbicka suggested that all the meanings involved be defined by means of Natural Semantic Metalanguage ${ }^{3}$. Despite its overall attractiveness, this suggestion is hardly suitable for the development of a database of semantic shifts, as that could only start after the NSM definitions are established for all English words we use as semantic labels. Nevertheless, we believe that these two tasks can be addressed concurrently. A part of the semantic labels we use are English "exponents" of semantic primitives (such as THINK, KNOW, WANT, FEEL, SEE, HEAR, CAN, SAY, LIVE, DIE, TIME, PLACE, and some others) or of English words which are already defined in the NSM framework (see e.g. Wierzbicka 1972, 1980, 1996, 1999, 2006). As the number of such words increases, we may apply these new entries to refine the substance of corresponding semantic labels used in the database. At the same time, modern lexical semantics is rather skeptical about the possibility of drawing a strict borderline between polysemy, vagueness, and context-conditioned variation (cf. Nerlich \& Clarke 2004: 4; Taylor 2004: 35). The recent usage- and exemplar-based approaches argue that every use is distinct and that broader conceptualizations represent inductive generalizations over the instances (cf. Croft \& Cruse 2004: 109ff.; Bybee 2010: 9). Thus, in order to introduce linguistic data into the database, we must map a semantic continuum of context-conditioned variants onto a set of discrete semantic labels. This inevitable simplification is counterbalanced by the fact that each lexeme that appears in a realization of a semantic shift has its dictionary definition provided along with it, as well as an example of its use

${ }^{1}$ I.e. proximity of corresponding concepts in a mental space accounting for various mechanisms of semantic derivation; cf. the list of "cognitive-associative relations" in [Koch 2004]. Other similar terms are "conceptual contiguity", "cognitive contiguity", "proximity in conceptual space", etc.

${ }^{2}$ The most frequent case is unidirectional shift $(\mathrm{A} \rightarrow \mathrm{B})$, other possibilities being bidirectional shifts $(\mathrm{A} \leftrightarrow \mathrm{B})$ and the shifts for which we cannot specify direction $(\mathrm{A}-\mathrm{B})$; see for more detail Zalizniak et al. 2012: 647.

${ }^{3}$ On the use of NSM in cross-linguistic semantic studies see Wierzbicka 1992, 1999, 2002, Goddard and Wierzbicka 1994, Gladkova 2005, Goddard 2008, 2012, Gladkova, Larina 2018 among others. 
in the meaning being considered. Additionally, we constantly revise and adjust the sets of sematic labels, semantic shifts, and their realizations as the work on the database progresses. Thus, we consider the process of cross-linguistic identification of meanings to be recursive.

If the same conflation of meanings occurs in comparable words of several languages, a semantic parallel arises ${ }^{4}$. For example, the semantic shift 'to reach' $\rightarrow$ 'to be sufficient' appears in the following linguistic units (each of them being a semantic parallel to all others):

1) Rus. dostat':

A: dostat' do potolka 'to reach up to the ceiling'

B: esli dostanet sil 'if (I) have enough strength $<$ to do it $>$ "

2) Rus. khvatat':

A: khvatat' za ruku 'to grab by the hand'

B: mne ne khvataet deneg 'I do not have enough money'

3) Germ. reichen:

A: er reicht mit dem Kopf fast bis zur Decke 'he pulls his head almost to the ceiling';

B: das Geld reicht nicht '(I) do not have enough money'

4) Sp. alcanzar:

A: alcanzar con la mano 'reach a hand $<$ to $\mathrm{smth}>$ ', alcanzar al techo 'to reach up to the ceiling'

B: Cuando el trabajo no alcanza para vivir 'when earnings are not enough to live on'; ¿Crees que tu conocimiento no alcanza? 'Do you think that your knowledge is not enough?'

The existence of several semantic parallels indicates that the given combination of meanings reflects a pattern of linguistic conceptualization ${ }^{6}$. Revealing such patterns is one of the tasks of the Catalogue of semantic shifts, which might also be called a "Catalogue of semantic parallels", since it represents a collection of semantic shifts reproduced in the languages of the world.

Depending on the nature of the relationship between linguistic units having the meanings $\mathrm{A}$ and $\mathrm{B}$ in a given language we distinguish the following types of realizations of a semantic shift?

\section{Synchronic polysemy:}

a) $\mathrm{A}$ and $\mathrm{B}$ are meanings of a polysemous word, e.g. Rus. golova 'head (= upper part of the body)' and 'head (= unit, when counting cattle, cf. 20 golov ovec

${ }^{4}$ On the use of semantic parallel in etymology and linguistic reconstruction see e.g. [Trubachev 1976, 1988, Wilkins 1996]. In lexical typology this phenomenon is called "polygenetic semantic parallels in semantic change", or simply "polygenesis" (Koch 2000, Gévaudan \& Wiebel 2004, Koch 2008).

${ }^{5}$ For this semantic shift see also Zalizniak, Toporova \& Yanin 2005, Zalizniak 2009, Rakhilina, Kor-Shain 2010.

${ }^{6}$ On the recurrence of a semantic shift as evidence of its cognitive significance see e.g. Brown and Witkowski 1983: 83; Sweetser 1990: 18ff, Traugott \& Dasher 2002: 11; Blank \& Koch 2000: 104; Koch 2000: 80; Koch 2004, 2008, Knyazev 2007: 45.

\footnotetext{
7 Cf. the notion "levels of colexification" in François 2008.
} 
'20 head of sheep')', Engl. to call 'to call $<$ smb. $>$ ' and 'to give a telephone call', Sp. sentir 'to feel' and 'to be upset'

b) $\mathrm{B}$ is the meaning of a word and $\mathrm{A}$ is the meaning of its stem used in a morphologically complex word, e.g.: Rus. žena 'wife' and ženolyub 'womanizer' (SSh 'woman' $\rightarrow$ 'wife'), Rus. syr 'cheese' and syrnik 'cottage cheese pancake' (SSh 'cottage cheese' $\rightarrow$ 'cheese'); Rus. revnost' 'jealousy' and revnostnyj 'zealous, fervent' (SSh 'zeal, fervency' $\rightarrow$ 'jealousy'). In this case the stem used in a morphologically complex word retains the diachronically primary meaning.

2. Diachronic semantic evolution of a word in one language or from an ancestor language to a descendant language, e.g. semantic shift 'zeal, fervency' $\rightarrow$ 'jealousy' which took place in Russian word revnost' during the last two centuries; from Old Rus. krasbnyj 'beautiful' to Rus. krasnyj 'red' (SSh 'beautiful' $\rightarrow$ 'red'); from Latin caput 'head' to French chef 'chief' (SSh 'head' $\rightarrow$ 'chief').

\section{Morphological derivation:}

a) [the main subtype] the meaning $B$ is represented by a morphological derivative from the word which has meaning A., e.g. Rus. slušat' - slušat'sya (SSh 'to listen' $\rightarrow$ 'to obey'), prostit' - prostit'sya (SSh 'to forgive' $\rightarrow$ 'to say goodbye'), Lat. capitulum 'chapter' from caput 'head' (SSh 'head' $\rightarrow$ 'chapter'); Sp. ventana from viento (SSh 'wind' $\rightarrow$ 'window'), Rus. okno from oko (SSh 'eye' $\rightarrow$ 'window'), ust'e from usta (SSh 'mouth' $\rightarrow$ 'mouth of a river'); Germ. anrufen from rufen (SSh 'to call $<$ smb. $>^{\text {' } \rightarrow} \rightarrow$ 'to give a telephone call'), It. zucchino from zucca ('pumpkin' $\rightarrow$ 'vegetable marrow')

b) vice versa, meaning $\mathrm{A}$ is represented by a morphological derivative from the word which has meaning B, e.g. Rus. ženščina 'woman' morpologicaly derives from žena 'wife' (SSh 'woman' $\rightarrow$ 'wife'), muž - mužčina (SSh 'man' $\rightarrow$ 'husband'); Germ. Mann - Mensch (SSh 'human being' $\rightarrow$ 'male'), Lat. puto - computo (SSh 'to calculate' $\rightarrow$ 'to have opinion');

c) the meanings A and B are expressed by different grammatical forms of the same word, e.g. Anc.Gr. eidon (aorist-2 form) 'to see' and oida (perfect form) 'to know'; Sp. celo 'zeal, fervency' and celos (plural form) 'jealousy'.

\section{Cognates:}

a) Meanings A and B belong to words of two sister languages diachronically going back to one and the same root in their common ancestor; e.g.: Germ. Zahl 'number' and Engl. tale 'story' (Germanic cognates, SSh 'to calculate' 'to narrate'); Rus. meškat' 'to be slow <in doing something>' and Pol. mieszkać 'live, inhabit $<$ in some place>' (Slavonic cognates); Lat. vertere 'to turn' and Germ. werden 'to become' (Indo-European cognates);

b) Words of a single language having a common ancestor: Rus. videt' 'to see' and vedat' 'to know'; Rus. golova 'head' and (borrowed from Ch.-Slav.) glava 'chapter'.

${ }^{8}$ Such linguistic data are traditionally interpreted as "motivational models", cf. Tolstaya 2002, 2008; Koch, Marzo 2007, Marzo 2009 among others. 
5. Borrowing: $\mathrm{B}$ is the meaning of a borrowed word in the recipient language, while $\mathrm{A}$ is the meaning of its source in the donor language, e.g. Rus. original'nyj 'peculiar, special' is a loanword, from Germ. original 'authentic, genuine' (Krysin 1998: 493); Rus. sortir derives from the Fr. verb sortir 'to go out' (SSh 'to go out' $\rightarrow$ 'WC').

Since semantic evolution includes a stage of polysemy ${ }^{9}$, a set of facts that testify a given semantic shift can be presented in the form of several realizations. For example, the SSh 'year' $\rightarrow$ 'summer' can be illustrated by the semantic evolution of the Rus. word leto, by the synchronic polysemy of the Old Rus. leeto (Sreznevskij 1989, II: 78), or by the synchronic polysemy of the contemporary Rus. leto which preserves its old meaning 'year' in bound use (cf. pyat' let 'five years') or as a part of a morphologically complex word (sf. mnogoletnij 'of many years'). The SSh 'zeal, fervency' $\rightarrow$ 'jealousy' can be testified, within the Rus. data, not only by the semantic evolution of the word revnost', but also by polysemy realization type, since the adjective revnostnyj 'ardent, earnest' retains the source meaning of the stem. As evidence for the semantic shift 'to hope' $\rightarrow$ 'to wait' one can use both the pair of cognate words Fr. espérer 'to hope' and Sp. esperar 'to wait', or the Lat. verb sperare having both meanings synchronically.

In CSSh, synchronic polysemy and attested semantic evolution are considered as the basic types of realization. However, in some cases the only reliable evidence of a semantic shift arises from comparison of two cognate words in modern languages.

One particular case of semantic shift is grammaticalization ${ }^{10}$, a shift where a target meaning is a grammatical one (i.e. belongs to the "universal grammatical inventory"), e.g. the Rus. verb sobirat'sya 'to pack up' has a derivative meaning 'to plan $<$ to do something >', which corresponds to the grammatical category "intentional prospective" (Plungian 2011: 387). The target meaning can also be "more grammatical" than the source meaning, cf. the analysis of the auxiliation of 'threaten' verbs in European languages in Cornillie 2004, Heine \& Kuteva 2006: 80 - 92. Grammaticalization as a specific class of semantic shift can manifest itself in various types of realizations: polysemy (e.g. Fr. aller - the verb 'to go' and an auxiliary verb in the grammatical form Futur immédiat); semantic evolution (e.g. Fr. avoir 'to have' derives from the Lat. habere 'to hold'); cognates (e.g. Fr. tenir 'to hold' and Port. auxiliary verb ter); morphological derivation, including any alteration of a morphosyntactic feature (e.g. Fr. connective de crainte que 'in order not to' derives from the verb craindre 'to be afraid', the Rus. conjunction xotya derives from a gerund form of the verb xotet' 'to want', the interrogative particle razve derives from a preposition meaning 'without, with the exception of' etc.).

A realization of a semantic shift thus occurs either when one word (wordstem) carries two meanings synchronically or diachronically or when a pair of cognate words diverge from a source word such that one carries meaning A while the other carries meaning B. Therefore, a semantic shift can be considered as an extension of the notion of polysemy due to the inclusion in the limits of $a$ word the possibility of diachronic,

\footnotetext{
9 Cf. Sweetser 1990: 9; 22, Blank 2000: 10, Koch 2001, Evans \& Wilkins 2000: 549, Traugott \& Dasher 2002: 16 among others.

${ }^{10}$ In an earlier version of this model (Zalizniak et al. 2012) grammaticalization was mistakenly considered to be one of the types of realization.
} 
dialectal and morphosyntactic variation ${ }^{11}$. Note that a similar extension of the scope of $a$ word is already de facto generally accepted in etymology (cf. Sweetser 1990); cf. also a similar approach to polysemy in Arkad'ev 2002, Tolstaya 2008: 20 (among others), the principles of defining enantiosemy in Shmelev 2009 and the notion of "loose colexification" in François 2008.

The notion of semantic shift as a unit of CSSh is close, but not identical, to the notion of semantic derivation. The term "semantic derivation" describes the phenomenon of more or less regular semantic change of a word that does not affect its form (cf. the term "regulyarnaya mnogoznačnost" in Apresjan 1974). The mechanism of semantic derivation presupposes a rule governing this process that makes it possible to generate derivative meanings of a certain type from original meanings of a certain class (Apresjan 1974, 2009, Nunberg, Zaenon 1992, Pustejovsky 1998, Paducheva 2004, Kustova 2004, among others). Semantic shift as a unit of CSSh presupposes no generative process or general rules governing formation of derivative meanings. Semantic shift reflects semantic associations between individual linguistic meanings (cf. the term "rapprochement sémantique" or "semantic association" used by Martine Vanhove (2008) and "sceplenie smyslov" ['concatenation of meanings'] in Stepanov 1995), and their regularity manifests itself in the fact that the same semantic shift reproduces itself independently in words with the same original meaning in different languages.

\section{SEMANTIC TYPOLOGY AS TYPOLOGY OF SEMANTIC SHIFTS}

The term "semantic typology" has several meanings. Since the object of semantic typology is linguistic meaning, this term can be understood in the broadest sense as a generic term with respect to all typologies that deal with meaningful units of language, including lexical typology. This interpretation is shared, for example, by Nicholas Evans who quotes the definition "characteristic ways in which language [...] packages semantic material into words" from Lehrer 1992: 249 and says that "since words are only one type of sign we consider lexical typology to be that sub-branch of semantic typology concerned with the lexicon" (Evans 2011: 505). According to this understanding, grammatical typology should also constitute a branch of semantic typology (in the broad sense) insofar it represents the study of how languages "package" grammatical meanings.

Under semantic typology in a narrow sense we understand the typology of semantic shifts, cf. a similar understanding of the term "semantic typology" in Trubachev 1988: 213, Gak 1998: 469, Hénault-Sakhno \& Sakhno 2001, 2005; cf. also the term "typology of polysemy" in Zevakhina 1985 and the term "typologie des rapprochements sémantiques" in Vanhove 2008.

Lexical typology as a branch of linguistics dealing with lexicalization patterns and the typology of lexical systems has a rather strong tradition (see e.g. Lehmann 1990, Talmy 2007, Koch 2001 among others). It should be noted that earlier this area was called "semantic typology", and for this reason "semantic typology" is mentioned among the six typologies in the seminal paper by Greenberg (1957). However, as it is rightly observed by Peter Koch (Koch 2001: 1142), Greenberg clearly meant "lexical-semantic"

11 With the only exception of the realization type "morphological derivation", subtypes (a) and (b). 
typology, which corresponds to "lexical typology" in the sense outlined above. St. Ullmann (1963) also identifies "semantic typology" as the typology of lexical systems.

The modern lexical typology deals with ways of linguistic categorization (=lexicalization) within conceptual domains and possible ways of distributing semantic material between lexemes as well as typologically relevant parameters of variation (cf. Rakhilina \& Plungian 2007, Maisak \& Rakhilina 2007, Britsyn et al. 2009, KoptjevskajaTamm 2015, Rakhilina \& Reznikova 2016, among others).

If we compare lexical typology and semantic typology in the narrow sense outlined above, we can see that they differ in the focus of the researcher's interest. The object of lexical typology is the structure of lexical (sub)systems and the distribution of semantic material between words. In contrast, the typology of semantic shifts takes as its object pairs of genetically related meanings - the words that express these meanings are nothing more than "exponents" of the conceptual contiguity they reveal.

From the standpoint of lexical typology, languages that "package semantic material into words" in similar ways, and particularly those that unite and oppose pairs of meanings in similar ways, belong to one and the same "type". So, for example, English and French, which do not draw lexical distinction between the meanings 'wife's mother' and 'husband's mother' (English mother-in-law, French belle-mère), belong to the same type, whereas Russian, which has two different words (tešča and svekrov'), belongs to another type. Russian, which does not differentiate between 'father's brother' and 'mother's brother', belong to another type than Old Russian, which had two different words (stryj and $u j$ ) and so on. From the standpoint of CSSh, if we do not consider such words as English mother-in-law polysemous ${ }^{12}$ these facts do not provide a basis for any conclusions, because in such cases there are no semantic shifts in any of the languages being compared. From a lexico-typological point of view, German and Russian present different systematic features with respect to the SSh 'male' $\rightarrow$ 'husband': Russian has two different words (muščina and muž), while German uses one and the same (Mann). Meanwhile, from the standpoint of CSSh, both languages belong to the same type, since the SSh 'male' $\rightarrow$ 'husband' is present in both languages: in the form of polysemy in German and in the form of morphological derivation in Russian.

The method of semantic maps, originally conceived for grammatical typology, is now commonplace in lexical typology (Croft 2003: 133-139, Haspelmath 1997, 2003, François 2008, van der Auwera 2008; for the newest findings in this area see Georgakopoulos \& Polis 2018 and http://web.philo.ulg.ac.be/lediasema/workshop/). The "classical" semantic map is a graph with nodes standing for meanings and edges between nodes standing for relationships between meanings. This method allows researchers to display the possibilities of linguistic articulation within a given conceptual domain and to compare variants chosen by different language; e.g. the semantic map proposed in François 2008 outlines meanings derived from the meaning 'to breathe' and possible patterns of their "colexification" across a dozen languages.

Another form of semantic map is a lexico-semantic table, as the investigated fragment of conceptual space may be mapped onto a one-dimensional scale (cf. the semantic map 'tree' _ 'wood' — 'forest' in Haspelmath 2003, the semantic map

12 See the discussion of the problem of polysemy vs. syncretism in Zalizniak et al. 2012: 645-646. 
for the meanings 'human being' — 'male' — 'husband' in Zalizniak 2006: 411). We would like to suggest a modified variant of the table from Koch 2001:

Table 1

\begin{tabular}{|c|c|c|c|c|c|}
\hline & $\begin{array}{l}\text { 'hair } \\
\text { on the head' }\end{array}$ & $\begin{array}{l}\text { 'hair } \\
\text { in the beard' }\end{array}$ & $\begin{array}{l}\text { 'hair on the human } \\
\text { body' }\end{array}$ & $\begin{array}{l}\text { 'hair on the animal's } \\
\text { body' }\end{array}$ & ‘wool' \\
\hline English & \multicolumn{4}{|c|}{ hair } & wool \\
\hline German & \multicolumn{4}{|c|}{ Haar } & Wolle \\
\hline Russian & \multicolumn{3}{|c|}{ volosy } & \multicolumn{2}{|c|}{ šerst' } \\
\hline Latin & \multicolumn{2}{|c|}{ capilli } & \multicolumn{2}{|c|}{ pilus } & vellus, lana \\
\hline French & cheveux & \multicolumn{3}{|c|}{ poil } & laine \\
\hline Italian & capelli & \multicolumn{3}{|c|}{ pelo } & lana \\
\hline
\end{tabular}

This method of presentation has two main characteristic features that distinguish it from the format used in the DatSemShift: firstly, there are more than two meanings compared; secondly, the problem of distinguishing between polysemy and semantic generality (syncretism) does not arise, as it is only the fact of colexification that matters (cf. Haspelmath 2003: 231, François 2008: 169). A lexico-semantic table can be transformed into a "lexical matrix" (see Georgakopoulos \& Polis 2018: 5, Table 3). Such a lexical matrix for the semantic map 'to wander' — 'to get lost' — 'to be wrong' 'to fornicate' has been suggested in Zalizniak 2001 (Table 2 below represents its modified version):

Table 2

\begin{tabular}{|l|c|c|c|c|}
\hline & 'to wander' & 'to get lost' & 'to be wrong' & 'to fornicate' \\
\hline Lat. errare & + & + & + & \\
\hline Old.-Russ. blouditi & + & & + & + \\
\hline Russ. bludit' & & & & \\
\hline Russ. bluzhdat' & + & & & \\
\hline Russ. zabludit'sya & & + & + & \\
\hline Russ. zabluzhdat'sya & & & + & \\
\hline
\end{tabular}

In the CSSh format this information can be represented as a chain of shifts, each of them displaying a set of realizations (including "loose colexification", e.g. realizations of the type "morphological derivation"):

(i) SSh 'to wander' $\rightarrow$ 'to get lost':

Lat. errare ("polysemy");

Russ. bludit' - zabludit'sya ("morphological derivation")

(ii) SSh 'to get lost' $\rightarrow$ 'to be wrong':

Lat. errare ("polysemy");

Russ. zabludit'sya - zabluzhdat'sya ("morphological derivation")

(iii) SSh 'to be wrong' $\rightarrow$ 'to fornicate':

Old-Russ. blouditi ("polysemy");

Russ. bludit' — zabluzhdat'sya ("morphological derivation")

The fact that these semantic shifts form a chain can be detected by carrying out an automated search for the same meaning in the SOURCE and TARGET class.

On the whole, one can say that the method of semantic maps is more suitable for "intra-domain connections" (cf. Sweetser 1990: 19), whereas the CSSh is more 
appropriate for describing "inter-domain connections". See also Smirnitskaya 2018 on the comparison of the semantic maps and the CSSh methodologies.

In recent years, the domain of lexical typology has expanded. Maria KoptjevskajaTamm includes in the scope of lexical typology a "semasiological perspective" concerned with the mechanisms of semantic derivation in addition to its main "onomasiological perspective" (Koptjevskaja-Tamm 2012). This expanded understanding is reflected in the volume "The Lexical Typology of Semantic Shifts" (Juvonen \& KoptjevskajaTamm 2016) which includes studies done from both perspectives.

Conceptually closest to the CSSh are two projects also realized in the form of computer databases-DECOLAR (Dictionnaire étymologique et cognitive des langues romanes, http://www.decolar.uni-tuebingen.de/) and LexiTypDia (Lexical change polygenesis - cognitive constants: The human body), see Blank \& Koch 2000; Blank et al. 2000, Koch et al. 2003, Gévaudan et al. 2003. Other initiatives close to the CSSh that should be mentioned include a project on the typology of semantic associations directed by Martine Vanhove (Vanhove 2008), an investigation of Russian-French etymological parallels by Serguei Sakhno (Sakhno 1999, 2001; Hénault-Sakhno \& Sakhno 2005), and the most recent project CLICS (Database of Cross-Linguistic Colexifications; see List et al. 2018).

The concept of a dictionary of semantic shifts goes back to ideas put forward in Buck 1971, Benveniste 1954, Schröpfer 1956, Trubachev 1964, Havlová 1965, Gak 1998.

\section{IDENTIFYING SEMANTIC SHIFTS: SOME PROBLEMATIC POINTS}

Identifying semantic shifts is a complex task, as there is no algorithm for this procedure. Although any attempt to collect and analyze a variety of linguistic facts as evidence for a certain semantic shift requires the use of certain methods and instruments, this process is not fully formalized and ultimately relies on the experience and intuition of the researcher.

The main problematic points that arise while identifying semantic shifts (discussed in Zalizniak 2001, 2008, 2013a, Zalizniak et al. 2012: 644-649) are:

- delimitation between polysemy and syncretism (semantic generality);

- establishment of the direction of a semantic shift;

- distinguishing between morphological derivation of subtype (a) that represents realization of a semantic shift $v s$. morphological derivation that represents a well-defined word-formation model (e.g. the pairs of words agree and disagree does not imply a semantic shift 'agree' $\rightarrow$ 'disagree');

- treatment of semantic calques and of the inherited polysemy;

- presentation of "multiple" semantic shifts.

Some additional considerations regarding the identification of semantic shifts should be added here.

1. CSSh presents semantic shift as a binary relation. In reality, semantic evolution as well as synchronic semantic derivation usually include more than two steps, and the boundaries between them are rather fuzzy. The "extraction" of pairs of discrete meanings that form relevant semantic shifts presents the more difficult part of the work. In doing this, we deliberately simplify the real picture of semantic evolution, leaving aside various attendant circumstances, including possible intermediate steps. 
For example, the French verb demeurer has undergone a semantic evolution from the meaning 'to be slow' (Lat. demorari) toward 'to dwell' (this is the main contemporary meaning of the French demeurer). An intermediate step of this evolution was 'to remain in some place for some time' [Rey 2000: 1031], with a derivative meaning 'to continue to be in a certain state'. The Latin verb demorari and French demeurer both possess other meanings as well. Deliberately simplifying the linguistic reality, we postulate the semantic shift 'to be slow' $\rightarrow$ 'to dwell'. Another example of such a simplification (reduction) of the real way of semantic evolution could be the semantic shift 'to ride' $\rightarrow$ 'to be ready < to do smth.>', realized in Engl. ride, ready (Blumfil'd 1968: 475) and Germ. reiten, bereit, includes an intermediary step 'ready to ride'; cf. a similar semantic shift demonstrated by Germ. words fahren, fertig (Paul' 1960: 110]). An intermediate step of the semantic shift 'to reach' $\rightarrow$ 'to be sufficient' mentioned above can be observed in the following uses cited in Dal's dictionary (Dal' 1994: IV, 1174): Ruž'e za reku ne khvatit 'the gun will not reach across the river', Šest ne khvataet dna 'the pole does not get to the bottom' etc. Reconstruction of the semantic history of individual words is an exciting research topic, but it cannot be realized by means of CSSh methodology. Semantic shift as a unit of the DatSemShift associates two meanings of given words, extracting them from a multitude (or rather a continuum) of meanings that they encompass. It is a conventional metalinguistic construction, and as such it has no chronology and no intermediate logical steps.

2. Although delimitation between polysemy and homonymy often is problematic, it is necessary because homonyms do not imply semantic shifts (cf. an opposite attitude towards homonymy in Georgakopoulos \& Polis 2018). For example, in Russian there are many homonymic prefixed verbs, which include the same prefix in different meanings, e.g. zalečit' ranu 'heal the wound' and zalečit' čeloveka 'make smb. worse by unskillful treatment'. Sometimes this difference results in a semantic contrast, which can be treated as enantiosemy, cf. examples from the article (Shmelev 2009): proslušat' vystuplenie - 'to listen to a speech' and 'to miss, not to catch what was said'; vyvodit' krolikov 'to breed, grow up rabbits' and vyvodit' tarakanov 'to exterminate cockroaches', zadut' sveču 'blow out the candle' and zadut' domnu 'blow a blast furnace', pereizbrat' $\langle X\rangle$ 'elect X again' and 'elect another person instead of X', obnesti 'to serve everybody' and 'pass over while serving'. However, such pairs do not imply the existence of a semantic shift 'A' $\rightarrow$ 'not-A'. Semantic contrast between two meanings of a prefixed verb is to some extent an accidental effect due to the use of different (but not opposite) meanings of the prefix (for more detailed discussion see Zalizniak 2006: 298-235).

3. The real direction of semantic shift may be opposite to what is observed. For example, in Old-Rus. the stem strad- with original meaning 'suffer' acquired a derivative meaning 'work'; thus Old-Rus. words stradati 'to work', stradnikъ 'worker', strada 'work' (Sreznevskij 1989, 3: 530-533) demonstrate the semantic shift 'to suffer' $\rightarrow$ 'to work' ${ }^{13}$. The meaning 'to work' subsequently has been lost over time. So, one might

13 The same semantic shift took place in Rus. stem trud-, with actual meaning 'work' and original meaning 'suffer' (Sreznevskij 1989, 3: 1007), which remains in the locution natrudit' nogu 'to hurt [one's] foot'; cf. also Fr. peine, which has passed the way of semantic derivation 'punishment' $\rightarrow$ 'suffering' $\rightarrow$ 'work' and preserves all three meanings in the form of synchronous polysemy (the last one only in the idiom ne vaut pas la peine 'not worth the trouble', cf. the Rus. equivalent ne stoit truda). 
mistakenly treat the pair Old-Rus. stradati and Rus. stradat' as a realization of the reverse SSh 'to work' $\rightarrow$ 'to suffer'. Meanwhile, this reverse semantic shift also exists, as in Lat. labor or in Sp. trabajo, both words having derivative meaning 'suffering'. In such cases we use a bidirectional arrow for the semantic shift in the Catalogue and specify the direction for each realization. Sometimes the direction of semantic shift cannot be established; in such cases, the associated meanings are related with a simple dash. See Zalizniak et al. 2012: 647 for more detail.

\section{CONCLUDING REMARKS}

The Catalogue of Semantic Shifts has clearly defined basic principles, its primary notions being those of a semantic shift, which is understood as a relation of cognitive proximity between two linguistic meanings, and a realization of a semantic shift, i.e. one polysemic word or a pair of cognate words that act as "exponents" of this relation. The typology of semantic shifts occupies a position at the crossroad of semantic, lexical and grammatical typologies, overlapping each of these areas of study in terms of linguistic data and methods used. However, the domain of CSSh does not coincide with any of them. The intersection with grammatical typology arises from the fact that grammaticalization is a specific case of semantic shift. The area of semantic typology does not have sharply defined boundaries, since any linguistic typology that has meaningful units as its object is semantic typology in a broad sense - therefore, we have termed the typology of semantic shifts "semantic typology in a narrow sense". Finally, the intersection with lexical typology (in its expanded sense) lies in the domain of its "semasiological perspective".

Today, twenty years since the project of a Catalogue of Semantic Shifts was initially formulated, the idea that synchronic polysemy and diachronic semantic evolution represent two complementary aspects of the same phenomenon has become a generally accepted fact and the foundation of modern theories of diachronic semantics. The framework of CSSh is the theoretical foundation for identifying recurring cross-linguistic semantic shifts, which we are subsequently collecting in a database, semantic shift being understood as an extension of the notion of polysemy. I sought to demonstrate that the notion of semantic shift as defined in CSSh is just a formalization of an instrument of linguistic analysis that is already quite common in various areas of linguistics. Semantic shift provides a basis for the notion of semantic parallel used in the historical linguistics and etymology, for motivational models in word-formation, it is a central notion for grammaticalization theory. Finally, semantic shift is one of various types of implicit meanings (along with presuppositions and connotations) that shape of the "linguistic model of the world" (Tolstaya 2002, 2008, Russo 2014, Zalizniak 2013b). Linguistic data contained in the Database of Semantic Shifts can be used in all these areas, in order to provide semantic plausibility criteria for linguistic reconstruction, to act as empirical evidence for cognitive mechanisms of linguistic conceptualization, or to aid in identifying specific features of the semantic system of a given language or group of languages.

(C) Anna A. Zalizniak, 2018

\section{FINANCE AND ACKNOWLEDGEMENTS}

This work was supported by RFBR (Russian Foundation for Basic Research), grant \# 17-29-09124.

I would like to express my gratitude to my colleagues: Maria Bulakh, Dmitrij Ganenkov, Ilya Gruntov, Timur Maisak and Maxim Russo for their work on creating the Database of Semantic Shifts in 
the Languages of the World that allowed the implementation of the idea of CSSh, as well as to Anna Dybo, Andrei Kibrik, Maria Koptjevskaja-Tamm, Irina Mikaelian, Tatjana Mikhajlova, Vladimir Plungian, Georgij Starostin and Andrei Zalizniak for the support of this work at its various stages.

I am also grateful to the anonymous reviewer of the Russian Journal of Linguistics for the positive feedback on my article and for the shortcomings noted, which were corrected in the final version.

\section{REFERENCES / СПИСОК ЛИТЕРАТУРЫ}

Apresjan, Yu.D. (1974). Leksicheskaya semantika (Lexical Semantics). Moscow.

Apresjan, Yu.D. (2009). Issledovaniya po semantike i leksikografii. T. 1. Paradigmatika. (Research in Semantics and Lexicography. Vol. I. Paradigmatics) Moscow. (In Russ.)

Arkad'ev, P.M. (2002). Polisemiya nazvanij golovy v slavyanskikh i germanskikh yazykakh v tipologicheskom i istoricheskom aspekte (Polysemy of Denominations for the Word "Head" in Slavic and Germanic Languages in the typological and Historical Aspects). Moskovskij lingvisticheskij zhurnal. 2002. T. 6. № 1. (in Russ.)

Benveniste, E. (1954). Problèmes sémantiques de la reconstruction. Word, vol. X, N²-3.

Blank, A. (2000). Polysemy in the Lexicon. In R. Eckarolt, K. von Heusinger (eds.). Meaning change meaning variation. Workshop held at Konstanz, Feb. 1999. Konstanz.

Blank, A., Koch, P. \& P. Gévaudan (2000). Onomasiologie, sémasiologie et l'étymologie de langues romanes: esquisse d'un projet. In A. Englebert, M. Pierrard, L. Rosier, D. Van Raemdonck (eds.) Actes du XXIIe Congrès International de Linguistique et de Philologie Romanes, Bruxelles, 23-29 juillet 1998. IV: Des mots aux dictionnaires. Tübingen.

Blank, A. \& P. Koch (2000). La conceptualisation du corps humain et la lexicologie diachronique romane In H. Dupuy-Engelhardt, M.-J. Montibus (eds.). La lexicalisation des structures conceptuelles: Actes du colloque international EUROSEM 1998. (Recherches en linguistique et psychologie cognitive 13.) Reims, 2000.

Blumfil'd, L. (1968). Yazyk (Language). Moskva. (in Russ.)

Brown, C.H. \& S.R. Witkowski (1983). Polysemy, lexical change and cultural importance. Man. New Series. 1983. V. 18. № 1.

Buck, C.D. (1971). A Dictionary of Selected Synonyms in the Principle Indo-European Languages. A Contribution to the History of Ideas. Chicago.

Bybee, J.L. (2010). Language, Usage and Cognition. Cambridge.

Cornillie, B. (2004). The shift from lexical to subjective readings in Spanish prometer 'to promise' and amenazar 'to threaten': a corpus-based account. Pragmatics, 2004, 14(1): 1-30.

Croft, W. (2003). Typology and Universals. 2nd edition. Cambridge: Cambridge Univ. Press.

Croft, W. \& D.A. Cruse (2004). Cognitive linguistics. Cambridge: Cambridge Univ. Press, 2004.

Dal', V.I. (1994). Tolkovyj slovar' zhivogo velikorusskogo yazyka (Explanatory dictionary of the living Great Russian Language) Moskva.

Evans, N. (2011). Semantic typology. In J.J. Song (ed.), The Oxford Handbook of Typology. Oxford: Oxford University Press.

Evans, N. \& D. Wilkins (2000). In the mind's ear: the semantic extension of perception verbs in Australian languages. Language. 2000. V. 76. № 3.

François, A. (2008). Semantic maps and the typology of colexification. In M. Vanhove (ed.). From Polysemy to semantic change. Towards a Typology of Lexical Semantic Associations. [Studies in Language Companion series, 106] Amsterdam, 2008.

Gak, V.G. (1998). Metafora: universal'noe i spetsificheskoe (Metaphor: the Universal and the Specific). Gak V.G. Yazykovye preobrazovaniya. Moskva. (in Russ.)

Gladkova, A. (2005). In what ways the Russian soperezhivanie is different from the English empathy? The Natural Semantic Metalanguage in contrastive semantics. Computational Linguistics and 
Intellectual technologies. Papers from the Annual International Conference Dialogue-2005, Zvenigorod, 1-7 June 2005. P. 107-112. Moscow. (In Russ.)

Gladkova, A. and T. Larina (2018). Anna Wierzbicka, Words and The World. Russian Journal of Linguistics, 22 (3), 499-520.

Georgakopoulos, Th. \& St. Polis (2018). The semantic map model: State of the art and future avenues for linguistic research. [wileyonlinelibrary.com/journal/lnc3].

Gévaudan, P., Koch, P. \& A. Neu (2003). Hundert Jahre nach Zauner: Die romanischen Namen der Körperteile im DECOLAR. Romanische Forschungen. Bd. 115. № 1.

Gévaudan, P. \& D. Wiebel (2004). Dynamic lexicographic data modeling: A diachronic dictionary. Proceedings of the Fourth International Conference on Language Resources and Evaluation (LREC'04) [http://www.lrec-conf.org/proceedings/lrec2004/pdf/471.pdf]

Goddard, C. (2008) (ed.). Cross-linguistic semantics. Amsterdam \& Philadelphia: John Benjamins.

Goddard, C. (2012). Semantic primes, semantic molecules, semantic templates: Key concepts in the NSM approach to lexical typology. Linguistics. 50 (3), 711-743.

Goddard, C. \& A. Wierzbicka (eds.) (1994) Semantic and lexical universals: Theory and empirical findings. Amsterdam: John Benjamins.

Greenberg, J.H. (1957). The nature and uses of linguistic typologies. International Journal of American Linguistics, 23 (2).

Haspelmath, M. (1997). Indefinite Pronouns. Oxford: Oxford University Press, 1997.

Haspelmath, M. (2003). The geometry of grammatical meaning: Semantic map and cross-linguistic comparison. In Tomasello M. (ed.). The new psychology of language. V. 2. Mahwah (NJ).

Havlová, E. (1965). O potřebe slovníku semantickych změn. Yazykovědné actuality. № 4.

Heine, B. \& T. Kuteva (2006). The Changing Languages of Europe. Oxford: Oxford Univ. Press.

Hénault-Sakhno, Ch. \& S. Sakhno (2001). Typologie des langues et sémantique diachronique: le problème des universaux. LINX. V. 45.

Hénault-Sakhno, Ch. \& S. Sakhno (2005). Typologie sémantique lexicale: problèmes de systématisation. In C. Moyse-Faurie, G. Lazard (eds.). Typologie linguistique. Villeneuve d'Ascq.

Juvonen, P. \& M. Koptjevskaja-Tamm (eds.) (2016). The lexical typology of sematic shifts. [Cognitive Linguistics Research, 58] Berlin: De Gruyter Mouton.

Knyazev, Yu.P. (2007). Grammaticheskaya semantika. Russkij yazyk v tipologicheskoj perspektive. (Grammatical Semantics: Russian Language in Typological Perspective.) Moskva: Yazyki slavyanskikh kul'tur, 2007.

Koch, P. (2000) Pour une approche cognitive du changement semantique lexical: aspect onomasiologoque. Memoires de la Société de linguistique de Paris. Nouvelle série, tome IX. Theories contemporaine du changement sémantique. Peeters, 75-95.

Koch, P. (2001). Lexical typology from a cognitive and linguistic point of view. In M. Haspelmath, E. König, W. Oesterreicher, W. Raible (eds.) Language typology and language universals: An international handbook. Vol. 2, 1143-1175. Berlin - N.-Y.: Walter de Gruyter.

Koch, P. (2004). Diachronic onomasiology and semantic reconstruction. In W. Mihatsch, R. Steinberg (eds.), Lexical Data and Universals of Semantic Change. Tübingen: Stauffenburg, 2004.

Koch, P. (2008). Cognitive onomasiology and lexical change. Around the eye In M. Vanhove (ed.) From Polysemy to semantic change. Towards a Typology of Lexical Semantic Associations. [Studies in Language Companion series, 106] Amsterdam: John Benjamins Publishing Company, 2008.

Koch, P., Gévaudan, P. \& A. Neu (2003). Dictionnaire Etymologique et Cognitif des Langues Romanes In Th. Städtler (hrsg.). Wissenschaftliche Lexikographie im deutschsprachigen Raum. Heidelberg: Universitätsverlag Winter, 195-207. 
Koch, P. \& D. Marzo (2007). A two-dimensional approach to the study of motivation in lexical typology and its first application to French high-frequency vocabulary. Studies in Language, vol. 31,2 .

Koptjevskaja-Tamm, M. (2012). New directions in lexical typology In M. Koptjevskaja-Tamm, M. Vanhove (eds.) New directions in lexical typology. Special issue of Linguistics. V. 50. № 3.

Koptjevskaja-Tamm, M. (2015). The linguistics of temperature. Amsterdam: John Benjamins.

Krysin, L.P. (1998). Tolkovyi slovar' inoyazychnykh slov. (Dictionary of Foreign Words.) Moskva. (In Russ.)

Kustova, G.I. (2004). Tipy proizvodnykh znachenij i mekhanizmy yazykovogo rasshireniya. (Types of Derivative Meanings and Mechanisms of Linguistic Expansion). Moskva: Yazyki slavyanskoj kul'tury. (In Russ.)

Lehmann, C. (1990). Towards lexical Typology. In W. Croft, K. Denning, S. Kemmer (eds.) Studies in Typology and Diachrony. Papers presented to Joseph H. Greenberg on his $75^{\text {th }}$ Birthday. Amsterdam, 1990.

Lehrer, A. (1992). A theory of vocabulary structure: Retrospectives and prospectives. In M. Putz (ed.) Thirty years of linguistic evolution. Studies in Honor of René Dirven on the occasion of his sixtieth Birthday. Amsterdam: Joh Benjamins.

List, J.-M., Anderson, C., Greenhill, S.J., Mayer, Th., Tresoldi, T. \& R. Forkel (2018). CLICS²: An Improved Database of Cross-Linguistic Colexifications Assembling Lexical Data with Help of Cross-Linguistic Data Formats. Linguistic Typology, 22, 277-306.

Maisak, T.A. \& E.V. Rakhilina (eds.) (2007). Glagoly dvizheniya v vode: leksicheskaya tipologiya. (Verbs of Movement in Water: Lexical Typology.) Moskva. (in Russ.)

Marzo, D. (2009). Polysemie als Verfahren lexikalischer Motivation. Theorie und Empirie am Beispiel von Metonymie und Metapher im Französischen und Italienischen. Tübingen.

Nerlich, B. \& D. Clarke (2004). Polysemy and flexibility: introduction and overview. In Z. Todd, V. Herman, D.D. Clarke (eds.). Polysemy: Flexible patterns of meaning in mind and language [Trends in Linguistics: Studies and Monographs, 142]. Berlin, New York, 2004.

Nunberg, G. \& A. Zaenen (1992). Systematic polysemy in lexicology and lexicography. Eurolex'92, Part II, 1992, 387-396.

Paducheva, E.V. (2004). Dinamicheskie modeli v semantike leksiki. (Dynamic Models in Lexical Semantics.) Moskva. (In Russ.)

Paul', G. (1960). Principy istorii yazyka (Principles of the History of Language). Moskva. (in Russ.)

Plungian, V.A. (2011). Vvedenie v grammaticheskuyu semantiku: grammaticheskie znacheniya i grammaticheskie sistemy yazykov mira. (Introduction to Grammatical Semantics: Grammatical Meanings and Grammatical systems in the Languages of the World.) Moskva. (in Russ.)

Pustejovsky, J (1998). The Generative Lexicon. MIT Press, Cambridge, MA, 1998.

Rakhilina, E.V. \& I. Kor-Shain (2010). Novaya zagadka khvatat'. (New Riddle of khvatat'.) In Rakhilina E.V. (red.) Lingvistika konstruktsij. Moskva: Azbukovnik, 318-332. (In Russ.)

Rakhilina, E.V. \& V.A. Plungian (2007). O leksiko-semanticheskoj tipologii. (About Lexico-Semantic Typology.) In Maisak T.A., Rakhilina E.V. (eds.), 9-26. (In Russ.)

Rakhilina, E.V. \& T.I. Reznikova (2016). A frame-based methodology for lexical typology. In Juvonen, P. \& M. Koptjevskaja-Tamm (eds.), 95-130.

Rey, A. (2000). Dictionnaire historique de la langue française. Paris: Dictionnaires LE RORERT.

Russo, M.M. (2014). Neogumbol'dtianskaya lingvistika i ramki «yazykovoj kartiny mira» (NeoHumboltdian Linguistics and the Boundaries of the "Linguistic Model of the World"). Politicheskaya lingvistika, № 47, 12-24. (In Russ.) 
Sakhno, S. (1999). Typologie des parallèles lexicaux russes-français dans une perspective sémanticohistorique. Slovo, v. 22-23.

Sakhno, S. (2001). Dictionnaire russe-français d'étymologie comparée. Correspondances lexicales historiques. Paris: L'Harmattan.

Schröpfer, J. (1956). Wozu ein vergleichendes Wörterbuch des Sinnwandels? Proceedings of the seventh International Congress of Linguists (London 1952). London: Clarendon Press.

Shmelev, A.D. (2009) «Neznachashchee» i «nevyrazhennoe» otritsanie (kognitivnye i kommunikativnye istochniki enantiosemii) ("Insignificant" and "Unexpressed" Negation (Cognitive and Communicative Origins of the Enantiosemy)). Logicheskij analiz yazyka. Asserciya i negaciya. Moskva: Indrik, 173-202. (In Russ.)

Smirnitskaya, A. (2018). The Database of semantic shifts 2.0 as a way to represent semantic variability. Presentation on the workshop "Semantic maps: Where do we stand and where are we going?". University of Liège. 26-28.6.2018 http://web.philo.ulg.ac.be/lediasema/wp-content/uploads/ sites/43/2018/05/Workshop_2018_LeDiasema_Posters.pdf.

Sreznevskij, I.I. (1989). Materialy $k$ slovaryu drevnerusskogo yazyka. (Material for the Dictionary of the Old Russian Language.) 3 volumes. Moskva. (In Russ.)

Sweetser, E. (1990). From Etymology to Pragmatics. Cambridge Studies in Linguistics 54. Cambridge: Cambridge Univ. Press.

Talmy, L. (2007). Lexical typologies. In T. Shopen (ed.). Language Typology and Syntactic Description. Vol. 3: Grammatical Categories and the Lexicon. 2nd edition. Cambridge.

Taylor, J. (2004). Cognitive models of polysemy. In Z. Todd, V. Herman, D.D. Clarke (eds.). Polysemy: Flexible patterns of meaning in mind and language [Trends in Linguistics: Studies and Monographs, 142]. Berlin, New York.

Tolstaya, S.M. (2002). Motivatsionnye semanticheskie modeli i kartina mira. (Motivational Semantic Models and the Image of the World.). Russkij yazyk v nauchnom osveshchenii. № 1 (3). (In Russ.)

Tolstaya, S.M. (2008). Prostranstvo slova. Leksicheskaya semantika v obshcheslavyanskoj perspektive. (The Space of a Word. Lexical Semantics in a General Slavic Perspective) Moskva: Indrik.

Traugott, E. \& Dasher, R. (2002) Regularities in semantic change. Cambridge: CUP.

Trubachev, O.N. (1964). 'Molchat' i 'tayat'. O neobkhodimosti semasiologicheskogo slovarya novogo tipa. ('Molchat' and 'tayat'. About the Necessity of a Semasiological Dictionary of a New Type). Problemy indoevropeiskogo yazykoznaniya. Moskva. (In Russ.)

Trubachev, O.N. (1976). Etimologicheskie issledovaniya i leksicheskaya semantika. (Etymological Research and Lexical Semantics). Printsipy i metody semanticheskikh issledovanij. Moskva.

Trubachev, O.N. (1988). Priemy semanticheskoj rekonstrukcii (Methods of Semantic Reconstruction). Sravnitel'no-istoricheskoe izuchenie yazykov raznykh semej. Teoriya lingvisticheskoj rekonstrukcii. Moskva: Nauka. (In Russ.)

Ullmann, St. (1963). Semantic universals. In Joseph H. Greenberg (ed.) Universals of Language. Cambridge: M.I.T. Press, 172-207.

van der Auwera, J. (2008). In defense of classical semantic maps. Theoretical Linguistics, 34, 39- 46.

Vanhove, M. (ed.) (2008). From Polysemy to semantic change. Towards a Typology of Lexical Semantic Associations. [Studies in Language Companion series, 106] Amsterdam: John Benjamins Publishing Company.

Wierzbicka, A. (1972) Semantic primitives. [Linguistische Forschungen. Bd 22]. Frankfurt am Main.

Wierzbicka, A. (1980). Lingua mentalis. The semantics of natural language. Sydney etc.: Acad. Press, 1980. 
Wierzbicka, A. (1992). Semantics, Culture, and Cognition. Universal Human Concepts in CultureSpecific Configurations. N. Y.; Oxford: Oxford Univ. Press.

Wierzbicka, A. (1996). Semantics: Primes and Universals. Oxford: Oxford Univ. Press.

Wierzbicka, A. (1999). Emotions across Languages and Cultures. Cambridge Univ. Press. Paris: Edition de la Maison des Sciences de l'homme.

Wierzbicka, A. (2002). Semantic primes and linguistic typology. In C. Goddard \& A. Wierzbicka (eds.) Meaning ad Universal Grammar. Theory and Empirical Findings. Vol. II, 257-300. Amsterdam: John Benjamins.

Wierzbicka, A. (2006). English: Meaning and Culture. Oxford: Oxford University Press.

Wilkins, D. (1996). Natural tendencies of semantic change and the search for cognates. In M. Durie, M. Ross (eds.). The Comparative Method Reviewed. Regularity and irregularity in Language Change. N.Y., Oxford: Oxford Univ. Press.

Zalizniak, A.A., Toropova, E.V. \& V.L. Yanin (2005). Berestyanye gramoty iz raskopok 2004 g. v Novgorode i Staroj Russe (Birch Bark Manuscripts Recovered in Novgorod and Staraya Russa in 2004). Voprosy yazykoznaniya, № 3. (In Russ.)

Zalizniak, Anna A. (2001). Semanticheskaya derivaciya v sinkhronii i diakhronii: proekt sozdaniya «Kataloga semanticheskikh perekhodov» (Synchronic and Diachronic Semantic Derivation: The Project of a "Catalogue of Semantic Shifts"). Voprosy yazykoznaniya, № 2. (In Russ.)

Zalizniak, Anna A. (2006). Mnogoznachnost'v yazyke i sposoby ee predstavleniya. (Linguistic Ambiguity and Ways of its Representations) Moskva: Yazyki slavyanskikh kul'tur. (In Russ.)

Zalizniak, Anna A. (2008). A Catalogue of Semantic Shifts: towards a Typology of Semantic Derivation. In Vanhove M. (ed.) From Polysemy to semantic change. Towards a Typology of Lexical Semantic Associations. [Studies in Language Companion series, 106] Amsterdam: John Benjamins Publishing Company, 217-232.

Zalizniak, Anna A. (2009) O ponyatii semanticheskogo perexoda (On the notion of sematic shift). Computational Linguistics and Intellectual technologies. Papers from the Annual International Conference Dialogue-2009, Bekasovo, 27-31 maya 2009, 107-112. Moscow. (In Russ.)

Zalizniak, Anna A. (2013a). Semanticheskij perekhod kak ob"ekt tipologii (Semantic Shift as an Object of Typology). Voprosy yazykoznaniya, 2013, № 2. (In Russ.)

Zalizniak, Anna A. (2013b). Russkaya semantika v tipologicheskoj perspektive: k voprosu o termine «yazykovaya kartina mira» (Russian Semantics from Typological Perspective: On the Notion of the "Linguistic Picture of the World"). Russian Linguistics. 2013. V. 37. № 1. (In Russ.)

Zalizniak, Anna A., Bulakh, M., Ganenkov, D., Gruntov, I., Maisak, T.\& M. Russo (2012) The Catalogue of semantic shifts as a database for lexical semantic Typology. Linguistics. V. 50. № 3.

Zevakhina, T.S. (1985). K voprosu ob universaliyakh v oblasti polisemii (About Linguistic Universals in Polysemy.). Lingvisticheskaya tipologiya. Moskva: Nauka. (In Russ.)

\section{Article history:}

Received: 05 September 2018

Revised: 25 September 2018

Accepted: 02 November 2018

\section{История статьи:}

Дата поступления в редакцию: 05 сентября 2018

Дата принятия к печати: 02 ноября 2018

\section{Для цитирования:}

Zalizniak, Anna A. The Catalogue of Semantic Shifts: 20 Years Later // Вестник Российского университета дружбы народов. Серия: Лингвистика = Russian Journal of Linguistics. 2018. Т. 22. № 4. C. 770 -787. doi: 10.22363/2312-9182-2018-22-4-770-787. 


\section{For citation:}

Zalizniak, Anna A. (2018). The Catalogue of Semantic Shifts: 20 Years Later. Russian Journal of Linguistics, 22 (4), 770-787. doi: 10.22363/2312-9182-2018-22-4-770-787.

\section{Bionote}

ANNA A. ZALIZNIAK is a Doctor of Philology, a Chief Researcher at the Institute of Linguistics of the Russian Academy of Sciences, a Leading Researcher at the Federal Research Centre of Computer Science and Control of the Russian Academy of Sciences. She has taught Russian linguistics at the universities of Paris, Aix-en-Provence, Florence and Munich. The sphere of her scientific interests includes general and Russian semantics, semantic typology, aspectology, word formation, conceptualization, pragmatics, intercultural communication. The main results of her research are reflected in more than 200 publications, including 8 books: "Explorations of the semantics of inner states" (1992), "Introduction into Russian aspectology" (co-authored with A.D. Shmelev, 2005), "Key ideas of the Russian linguistic picture of the world" (co-authored with I.B. Levontina and A.D. Shmelev, 2005), "Polysemy and means of its representation (2006), "Russian semantics in a typological perspective" (2013) and others. She is the author of the conception of semantic typology as the typology of semantic shifts; this conception gave rise to "Database of semantic shifts in languages of the world".

Contact information: anna.zalizniak@gmail.com

\section{Сведения об авторе}

ЗАЛИЗНЯК АННА АНДРЕЕВНА - доктор филологических наук, главный научный сотрудник Института языкознания Российской академии наук, ведущий научный сотрудник Федерального исследовательского центра «Информатика и управление» Российской академии наук. В 90-е годы преподавала русскую лингвистику в университетах Парижа, Экс-ан-Прованса, Флоренции, Мюнхена. Область научных интересов: общая и русская семантика, семантическая типология, аспектология, словообразование, языковая концептуализация, прагматика, межкультурная коммуникация. Основные результаты исследований изложены в более, чем 200 публикациях, в том числе 8 монографиях: «Исследования по семантике предикатов внутреннего состояний (1992); «Введение в русскую аспектологию» (в соавторстве с А.Д. Шмелевым, 2000); «Ключевые идеи русской языковой картины мира» (в соавторстве с И.Б. Левонтиной и А.Д. Шмелевым; 2005); «Многозначность в языке и способы ее представления» (2006), «Русская семантика в типологической перспективе» (2013) и др. Автор концепции семантической типологии как типологии семантических переходов, на основе которой создана «База данных семантических переходов в языках мира».

Контактная информация: anna.zalizniak@gmail.com 